\title{
The Impact of Using YouTubes and Audio Tracks Imitation YATI on Improving Speaking Skills of EFL Learners
}

\author{
Mona M. Hamad ${ }^{1}$, Amal Abdelsattar Metwally ${ }^{2} \&$ Sabina Yasmin Alfaruque ${ }^{3}$ \\ ${ }^{1}$ English Department, College of Science \& Arts Muhayil, King Khalid University, Saudi Arabia \\ ${ }^{2}$ English Department, Faculty of Languages and Translation, King Khalid University, Saudi Arabia \\ ${ }^{3}$ English Department, College of Science \& Arts Al-Majardah, King Khalid University, Saudi Arabia \\ Correspondence: Mona M. Hamad, English Department, College of Science \& Arts Muhayil, King Khalid \\ University, Saudi Arabia.
}

Received: April 18, 2019 Accepted: May 19, 2019 Online Published: May 21, 2019

doi: 10.5539/elt.v12n6p191 URL: https://doi.org/10.5539/elt.v12n6p191

\begin{abstract}
The purpose of this study is to shed light on a developed approach to be adopted in EFL speaking classes and show the effectiveness of using YouTube videos and Listening Audio Tracks Imitation (YATI) for teaching English language in speaking classrooms as pedagogical tools to improve EFL learners' speaking skills. To find out the impact of using You Tubes and Audio Tracks Imitation (YATI) on improving speaking skills of EFL learners, the qualitative experimental approach is used to conduct this study. The participants of this study are 48 students studying major English, divided into two sections studying Listening \& Speaking Course at College of Science \& Arts Muhayil, King Khalid University. One section was used as a control group and the other as an experimental group. Data was collected using speaking tests results which were analyzed using SPSS Pearson correlation coefficient. The results revealed that employing YATI technique has a positive impact on the effectiveness of the speaking skills, fluency and pronunciation of EFL learners. This study concluded that YouTube videos and Listening Audio Tracks Imitation (YATI) is a very effective CALL (Computer-Assisted Language Learning) tool towards improving students' speaking skills. This study recommends the use of YATI approach in order to help students overcome speaking problems.
\end{abstract}

Keywords: impact, imitation, YATI

\section{Introduction}

Listening and speaking are related to each other; what we listen as input, we speak as output. So, aural and oral skills cannot be excluded from each other. Speaking skills help speakers to communicate effectively; teaching speaking skills to non- native speakers where English is taught as a foreign language has always been a big challenge for the teachers, students don't practice enough listening to learn the right style of speaking, limited practice to listening resulted weak speaking skills. Lack of vocabulary along with the inability to pick up the tone and intonation puts a big hindrance to the non-native speakers. Keeping features like stress, accent and pronunciation in mind, achieving speaking skills such as: body language, right pronunciation of English letters, intonation, confidence, and correct usage of vocabulary is always a problem that is faced by both teachers and learners. Whenever they succeed to achieve one, they fail to achieve the other.

Bygate (2001, edited in Carter \& Nunan, 2001) states, speaking has occupied a peculiar position throughout the history of language teaching and has begun to emerge as a branch of teaching, learning and testing for only two decades. Bygate concludes that there are three reasons for this. 1) Using the traditional grammar translation methods. 2) Using tape-recording has been sufficiently cheap and practical to be used in classroom since 1970s. 3) Language teaching approaches are limited to oral skills to pronunciation. Until recently, speaking has become a special area in language teaching.

\subsection{Technology and Language Learning}

Technology has a significant role in language teaching and learning. In fact, technology offers learners many online materials and websites for learning, as well as search engines and databases which constitute an incredible source of information. Technology motivates students to learn and keeps them engaged for long time. Many researchers have observed that learners can learn better when they watch authentic and real-life clips (Maness 
2004). Furthermore, many researches propose that a significant number of technologies and online materials can be integrated into traditional EFL classrooms. On the same track, the present study focuses on using YouTube videos and audio tracks as a comprehensive technique to acquire speaking skills through imitation. Hamad M. Mona (2017) investigated using WhatsApp as very effective techniques that enhanced students learning and enthusiasm, and helped them to develop learning skills. YouTube videos and tracks were sent using WhatsApp to the students to make materials available to them.

\subsection{Speaking Skills}

"Speaking is a demanding skill" (Alonso, 2014, p. 147). It is one of the four important language basic skills, and along with writing, it is a very significant skill of language production that enables learners to communicate with others effectively. According to Byrne (1986), speaking is 'oral communication' in a two way process between the speaker and listener(s) involving both productive (i.e. speaking) and receptive skills (i.e. listening with understanding). Achmad and Yusuf (2014: 153) highlight that in speaking class, teachers are required to create communicative and interactive activities by giving students time, opportunities and motivation to practice the target language.

Intended Learning outcomes (ILOs) of Listening \& Speaking-3 course are the following:

- Understand general gist of spoken texts.

- Demonstrate knowledge on how to ask questions and make requests politely.

- Respond to the ideas in spoken texts effectively while participating in a conversation.

- Identify and understand verbal cues in speaker attitude and tone.

- Apply the knowledge of context to workout unknown vocabulary.

- Synthesize what they have heard and apply it to their own experience.

- Demonstrate the understanding of spoken texts, short and informal presentations on an experiential topic, and social communication.

\subsection{Aim of the Study}

This study aim at finding the impact of using YouTube and Audio Tracks Imitation YATI on language acquisition and language learning in listening and speaking classes of students who learn English as foreign language, focusing on speaking fluency and performance improvement using CALL to send materials to achieve (ILOs) of the course .

\section{Review of Literature}

\subsection{Literature Review Related to YouTube Videos}

YouTube has become one of the most-popular websites in the world (Alexa, 2011). It is considered a source of online material that has a significant role in language teaching and learning. It also provides students with everyday language videos and authentic live situations that could help them improve their understanding, performance and production of English language.

Many studies have been conducted on the use of technology in language teaching and learning. Hismanoglu (2012) indicated that bringing technology in the classroom helps both teachers and learners to create good learning environment in order to enhance the teaching and learning processes. Whithaus and Neff (2006) asserted that teachers can use videos as a Web-based mode of teaching and gave students the opportunity to use videos for self-learning. More significantly, many researchers have tried to shed light on the vital role of YouTube videos for teaching and learning in classrooms. Duffy (2008) affirms that YouTube is being increasingly used by teachers to teach English language as it offers fun and fast access to instruction, culture-based videos, and languages from all over the world. Moreover, Alhamami (2013) explores the use of YouTube LLVs as complete language lessons that do not require supplementary language materials.

Sunardi, etal (2018) revealed that storytelling model consistently showed an increase in students' learning and storytelling skills, and the suggestopedia based teaching model using authentic themes taken from students' actual experiences were more relevant to the students' conditions, needs, interests, and abilities. As a result, the learning was more interesting and meaningful. The results implied that the teaching model prototype can be further developed to increase the primary students' story telling skill in Salatiga.

\subsection{Literature Review Related to Using Audio Tracks}

Tryanti et al. (2018) asserted that podcast has significant impact on students' listening comprehension, and raised 
students motivation to learn English. LouafiAmina (2017) examined the effectiveness of implementing E-Learning tool in oral expression class in enhancing students' oral competency and found that the integration of podcasts in EFL classrooms has a positive effect on learners' oral proficiency, and it increases their motivation and participation while learning in an interactional environment, and it exposes them to the authentic spoken English where they can acquire vocabulary, pronunciation, and they would know how English language is spoken according to specific contexts. Islam et al. (2017) according to finding suggested that podcasts can be used in English classes to develop listening ability among Iranian EFL learners. Shahid and Zuraina (2017) affirmed that video-podcasts are useful resources for enhancing EFL listening comprehension. Rahman, Haryanto and Kisman (2018) indicated that the podcasts had the huge potential to help learners in improving their listening comprehension besides developing students' achievement compared to those who don't used podcasts. Moreover, a majority of the students approved that podcasts are fascinating in teaching listening comprehension. Djebbari Hassen (2016) revealed that podcasts play a significant role in EFL teaching and learning, which confirmed the effectiveness of podcasts as an e-tool that enhances their listening skills, as well as its usefulness in language learning. Moreover, it fulfills the teachers' needs to deliver listening courses in a comfortable and easy way. Astrimardila and Erwin (2017) revealed that there is potential achievement in using technology that affected both students and teachers. Students enthusiastically engaged themselves to sharpen their English learning achievements; listening and speaking with technology experiences, obtained various instructions and interesting learning atmosphere. The teacher developed his ability in using integrated technology tools (such as Podcasts) to perform a creative instruction in classroom setting. Podcasts provided tremendous topics and activities which enrich teachers' and students' knowledge as well as mastery of their skills in educational purpose. Shahid (2017) findings imply that video-podcasts are useful resource for enhancing EFL learners' listening comprehension. However, their appropriate length needs to be considered for the desired results. Robi (2016) indicated that students had positive attitude towards podcasts, as it helped them in learning English, the clear native pronunciation derived from podcast engaged their interest and made learning more exciting. However, students can face many problems such as too long podcasts or the availability of internet access.

\section{Methodology}

\subsection{Data Collection}

This study used the qualitative experimental approach to find out the impact of using You Tubes and Audio Tracks imitation (YATI) on improving aural and oral skills focusing on improving speaking skills of EFL learners.

\subsection{Participants}

The participants of this study are 48 students studying major English; 24 students in each section; studying Listening and Speaking course in level 3, at College of Science \& Arts Muhayil, King Khalid University in the $1^{\text {st }}$ semester of the Academic year 1438-1439.

\subsection{Instrument of the Study}

Two tests were used to collect the data, pretest for both sections, and posttest after using (YATI) approach with experimental group.

\subsubsection{Reliability and Validity of the Pretests}

To ensure the parity achievement of the pretest scores between the experimental group and control group, the grades were monitored in the academic year $(1438-1439 \mathrm{H})$. The following table shows the homogeneity of the two sections.

Table 1. Homogeneity of the pretest for the two sections

\begin{tabular}{llllllll}
\hline & Group & Mean & Std. Deviation & $\mathrm{t}$ & $\mathrm{df}$ & Sig. (2-tailed) & reality of 0.05 \\
\hline Exam & control & 7.375 & 1.454 & 0.875 & 46 & 0.386 & insignificance \\
\hline
\end{tabular}

It is clear from the above Table 1 that the probability value is non-denomination, which means there is homogeneity between the two groups, which indicates that there are no statistical differences in the performance rate in the pretest between the control and the experimental group. 


\subsubsection{Reliability and Validity of the Posttest}

To find the reliability and validity of the posttest, the researchers used correlation coefficient using Pearson, Spearman and Brown which approved the validity of the posttest indicating a high level of positive indicators to be used as a posttest, see Table 2 .

Table 2 . Reliability and validity of the posttest

\begin{tabular}{lll}
\hline & Pearson & Spearman \& Brown \\
\hline Reliable & .987 & .985 \\
Validity $=\sqrt{ }$ Reliable & 0.993 & 0.992 \\
\hline
\end{tabular}

\subsection{Study Design}

Participants of this study are from two sections from English department, each section consisting of 24 girl students of level three studying Listening \& Speaking course at Muhayil College, King Khalid University. One section is used as a control group, and the second section is used as an experimental group. Both sections who have been taught traditionally at the beginning of the course, took the speaking pretest, then the experimental section has been taught using YATI approach for six weeks, and the control group has been taught using the traditional approach at the same time then both sections took the same speaking posttest, results were analyzed to find the impact of using YATI approach on speaking skills.

\section{Statistics Analysis and Results}

Students sat for the speaking pretest and the post test, results were analyzed using SPSS to find out if YATI approach has impact on speaking skills. See Table 3, the result of the posttest average of two independent groups to see significant differences between experimental group using YATI approach, and control group using the traditional approach.

Table 3. The result of the posttest average of two independent groups

\begin{tabular}{llllllll}
\hline & Group & Mean & Std. Deviation & $\begin{array}{l}\text { Value of (t) } \\
\text { Calculated }\end{array}$ & df & Sig. (2-tailed) & reality of 0.05 \\
\hline \multirow{2}{*}{ Exam } & $\begin{array}{l}\text { experimental } \\
\text { control }\end{array}$ & 8.1667 & 1.10007 & 2.187 & 46 & 0.034 & significance \\
\hline
\end{tabular}

The results in the table above which reflects using T- test of two independent sections clearly show the differences between students learning outcome of Listening \& Speaking course using the traditional approach and the YATI approach. We find that the independent sample of t-test calculated was (2.187) with (46) degree of frequency, and Sig(one-tailed) (0.034) which approves there is a significant difference between the students' learning outcome of the course for those who learnt Listening and Speaking by YATI approach to those who learnt by traditional approach with (0.034) degree of frequency. It also shows that there are significant differences between the averages of students' learning outcomes who are studying Listening \& Speaking Language course using the YATI approach compared to the students who are studying the same subject learnt by the traditional approach. Students' performance was calculated using the evaluation sheet in Appedix 3.

Results of the posttest showed a clear difference between students' performance in the speaking posttest which shows the impact of using YATI approach to develop students' speaking skills, (see Figure 1). It illustrates the difference between the students' results in the speaking posttest of the experimental and the control group after using YATI approach. 


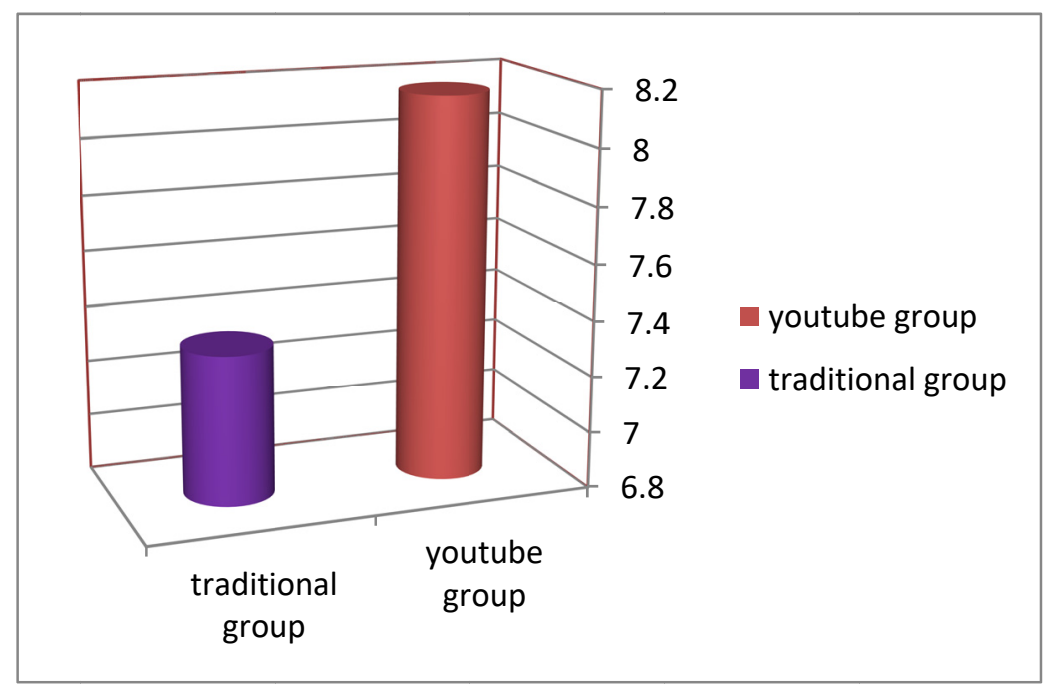

Figure 1. Comparison of speaking posttest results

To apply the (YATI) approach on the experimental group students, video clips were selected from some well-known fables which they enjoyed reading while in primary school (See Appendix 2). The language was very simple and the vocabularies were very common. They watched with great interest for 10 to 15 minutes, and then each of them was invited to narrate the story with her limited vocabulary. At first, they grappled with words and then when called to enact in a group, a clear enthusiasm and moral boosting was noticed. They spoke better with the peers as everyone tried to help each other in recollecting and reinforcing the words they heard and uttered later. The videos were selected very carefully where they can come across the same words used again and again. For example, a short video clip of the famous bed time story, 'Little Red Riding Hood' was selected first followed by 'Three Little Wolves' and then 'The Wolf and the Bears' where they heard many repetitions of the same words. Subsequently, short video clips downloaded from YouTube and other sources were sent to students using WhatsApp; they were asked to watch the You Tubes and imitate next day in the class what they have seen. Many audio tracks have been sent to the students with transcripts (see Appendix 1) and they are asked to imitate what they have listened using the correct voice tone, pronunciation and intonation. Enthusiasm of the students and confidence development of speaking skills were observed by the researchers inside the class.

\section{Discussion and Conclusion}

Speaking can't be taught formally; unlike grammar, we can't frame a particular set of rules to be crammed and cracked for developing speaking skill. It needs environment where one can listen continuously and pick up the skill involuntarily. It needs a ground for imitation and repetition for the enhancement of the skill. The average age of level-3 students lies between 16-20 years, which is a suitable age for the quick absorption of knowledge. This is the age they crave for smart phones with modern technology and popular Apps. They are highly motivated to learn any skill using these attractive devices. Their addiction to smart phones and covetous Apps can best be explored to enhance their speaking skill through YATI.

The result of using YATI approach on speaking skill was slow at first, but steady improvement was noticed not only in speaking, but also in students' listening skill of the experimental section progress was slow at first, as the students were reluctant to do imitating, they were afraid to make mistakes in front of their mates, or be in a funny situation. An audio track which had to be played three to four times earlier could be played just twice to achieve the same output. The impact of YATI was noticeable in students' confidence and intonation and fluency. Students were able to imitate the You Tubes video clips and audio tracks sent to them earlier more confidently. They were able to imitate the actions and the sounds they have watched as if they were native speakers. Unlike earlier, they started speaking effortlessly and more fluently with lesser tendency of thinking of the words before speaking. Results of this study agree with Hamad (2017) and Hismanoglu (2012) fining shows that using technology in classrooms enhances students learning and teaching as well, results also agreed with Whithaus and Neff (2006) finding, that using videos as a Web-based mode gave students the opportunity to use videos for self-learning, moreover, results correspond Duffy (2008) findings that using YouTube offers fun and fast access to instruction, culture-based videos, and languages from all over the world .Finding of this study agreed with Alhamami (2013) who pointed that using of YouTube LLVs can be a complete language lessons that do not 
require supplementary language materials. Also using story telling results make learning enjoyable and full of fun, this agreed with Sunardi et al. (2018). Using YATI approach impacted students' listening comprehension positively this agreed with Shahid and Zuraina (2017) study.

Results of this study agree with most studies reviewed above relating to using YouTubes and using audio tracks imitation to develop speaking skills, the imitation of the clips made the students able to try and develop their performance having a model to follow. Although some may say YATI deprives students from using their talents, the researchers of this study insist that using YATI approach helped students to discover their talents and abilities. YATI helps the students to have a target speaking average to reach. YATI makes the students proud of their performances, as they have no real contact with native speakers that they can practice their speaking skill with, considering that, their class is the only place where they can practice speaking; YATI makes the students competitive who try to give the best performance in front of their mates.

In the end the development of aural and oral skills and quick response of interaction is noticed while testing the experimental group compared to results of the control group, this makes YATI approach a successful tool that can be developed and used by curriculum designer to develop aural and oral proficiency of EFL learners according to desired leaning outcome.

\section{Declaration of Conflicting Interests}

On behalf of all authors, the corresponding author states that there is no conflict of interests.

\section{References}

Abd. Rahman, H. A., \& Kisman, S. (2018). Podcast Effects on Learners EFL Learners Listening Comprehension, Faculty of Language and Education, State University of Makassar, St.GunungsariBaru. BontoLangkasa, Makassar, Indonesia. Retrieved from: http://eprints.unm.ac.id/10166/1/jurnal.pdf

Achmad, D., \& Yusuf, Y. Q. (2014). Observing Pair-work in An English Speaking Class. International Journal of Instruction, 7(1).

Alexa.com. (2014). Alexa Top 500 Global Sites.

Alhamami, M. (2013). Observation of YouTube language learning video (YouTube LLVS). Teaching English with Technology, 13(3), 3-17.

Alonso, A. R. (2014). Teaching Speaking: An Exploratory Study in Two Academic Contexts. PORTA LINGUARUM 22, Junio 2014.

Amina. (2017). The Impact of Listening to Educational Podcasts on EFL Learners (MA Diss., University of Mohammed Kheider Biskra).

Byrne, D. (1986). Teaching Oral English. England: Longman.

Darwis, R. (2016). Students' Prospections towards The use of Podcast in Learning English, A Case Study of the Second Grade Students at One High School in Bandung. Journal of English and Education, 4(2), 80-100.

Duffy, P. (2008). Engaging the YouTube Google-Eyed Generation: Strategies for Using Web 2.0 in Teaching and Learning (pp.173-182).

Essays, U. K. (November 2013). The speaking skill. Retrieved from https://www.ukessays.com/essays/ education/the-speaking-skill.php

Hamad, M. M. (2017). Using WhatsApp to Enhance Students' Learning of English Language. Experience to Share. Higher Education Studies Journal, 7(4). https://doi.org/10.5539/hes.v7n4p74

Hassen, D. (2016). The Influence of Podcasts on EFL Student's Listening Comprehension (MA. Diss., University of Mohammed Kheider Biskra).

Hismanoglu, M. (2012). The Impact of Globalization and Information Technology on Language Policy in Turkey. Procedia-Social and Behavioral Sciences, 31, 629-633. https://doi.org/10.1016/j.sbspro.2011.12.115

Maness, K., (2004). Teaching Media-Savvy Students about the Popular Media. The English Journal, 93(3), 46-51. https://doi.org/10.2307/4128808

Namazian, D. I., Bohloulzadeh, G., \& Rahmatollahi, R. (2017). The Effects of Using Podcast on Listening Comprehension among Iranian Pre-intermediate EFL Learners. International Journal of Applied Linguistics and English Literature, 6(6). https://doi.org/10.7575/aiac.ijalel.v.6n.6p.57

Ramli, A., \& Kurniawan, H. E. (2017). The Use of Podcast to Improve Students' Listening and Speaking Skills 
for EFL Learners. Advances in Social Science, Education and Humanities Research, 145.

Shahid, S. H., \& Ali, Z. (2017). Effects of Video-Podcast on Listening Comprehension of Saudi EFL Learners. Europian Journal of English language Teaching, 2(4).

Shahid, S. H., \& Ali, Z. (2017). Finding the Best Length of Video-Podcasts: Effects of Varied numbers of Video-Podcast Used on Listening Comprehension of Saudi Undergraduates. International Journal of Novel Research in Education and Learning, 4(5), 19-33.

Sunardi, H. J. W., Astini, S., \& Nugraheni, E. W. (2018). Suggestopedia Based Storytelling Teaching Model for Primary Students in Salatiga. Malaysian Online Journal of Educational Technology, 6(1).

Tryanti, R. A., Nonny, B., \& Moh, R. W. (2018). The Impact of Podcasts on EFL Students' Listening Comprehension. International Journal of English Linguistics, 8(6). https://doi.org/10.5539/ijel.v8n6p122

Whithaus, C., \& Neff, J. M. (2006). Contact and interactivity: Social constructionist pedagogy in a video-based, management writing course. Technical Communication Quarterly, 15(4), 431-456. https://doi.org/10.1207/ s15427625tcq1504_2

\section{Appendices}

Appendix 1.

\section{Audio Tracks used in the trial}

Open Forum 2, Chapter 3, listening section retrieved from

https://elt.oup.com/elt/students/openforum/audio/of2_01.mp3?cc=sa\&selLanguage=en

Open Forum 2 Chapter 3 transcriptretrieved from

https://elt.oup.com/elt/students/openforum/pdf/of2_ts03.pdf?cc=sa\&selLanguage=en

Open Forum 2 Chapter 5, listening section retrieved from

https://elt.oup.com/elt/students/openforum/audio/of2_05.mp3?cc=sa\&selLanguage=en

Open Forum 2 Chapter 5 transcriptretrieved from

https://elt.oup.com/elt/students/openforum/pdf/of2_ts05.pdf?cc=sa\&selLanguage=en

Open Forum 2 Chapter 7, listening sectionretrieved from

https://elt.oup.com/elt/students/openforum/audio/of2_07.mp3?cc=sa\&selLanguage=en

Open Forum 2 Chapter $7 \&$ transcriptretrieved from

https://elt.oup.com/elt/students/openforum/pdf/of2_ts07.pdf?cc=sa\&selLanguage=en

It the thought that count. retrieved from

https://www.bbc.co.uk/programmes/p02pc9zn/episodes/downloads

It leaves a bad taste in my mouth retrieved from

https://www.bbc.co.uk/programmes/p02pc9zn/episodes/downloads

Throw in the towel

https://www.bbc.co.uk/programmes/p02pc9zn/episodes/downloads

A walk in the park

https://www.bbc.co.uk/programmes/p02pc9zn/episodes/downloads

\section{Appendix 2}

YouTubes used in the trial

How to be a mind reader? Retrieved from

https://www.youtube.com/watch?v=1Z3-wUPThYY

The power of words retrived from

https://www.youtube.com/watch?v=SQIWRwcN6Xs 
7 Principles To Live By For A Successful, Happy Life - Motivational Video retrieved from https://www.youtube.com/watch?v=EUoKyjBIoE8

10 Habits Of All Successful People!retrived from

https://www.youtube.com/watch?v=Dk20-E0yx_s\&t=43s

\section{Appendix .3}

Evaluation sheet for speaking tests

\begin{tabular}{|c|c|c|c|c|c|c|c|}
\hline$\underline{\text { No }}$ & Name & $\begin{array}{l}\text { Pronunciation } \\
\text { (Grammar, } \\
\text { vocabulary }) \\
\underline{(2 \text { marks })}\end{array}$ & $\begin{array}{l}\underline{\text { Fluency and }} \\
\underline{\text { Confidence }} \\
\underline{(2 \mathrm{marks})}\end{array}$ & $\begin{array}{l}\text { Intonation } \\
(1 \text { mark })\end{array}$ & $\begin{array}{l}\underline{\text { body }} \\
\underline{\text { language }} \\
\underline{(2 \mathrm{marks})}\end{array}$ & $\frac{\text { Content }}{(3 \text { marks })}$ & $\begin{array}{l}\text { Total } \\
\underline{10 \mathrm{marks})}\end{array}$ \\
\hline$\underline{1}$ & & & & & & & \\
\hline$\underline{2}$ & & & & & & & \\
\hline$\underline{3}$ & & & & & & & \\
\hline$\underline{4}$ & & & & & & & \\
\hline$\underline{5}$ & & & & & & & \\
\hline$\underline{6}$ & & & & & & & \\
\hline$\underline{7}$ & & & & & & & \\
\hline$\underline{8}$ & & & & & & & \\
\hline$\underline{9}$ & & & & & & & \\
\hline$\underline{10}$ & & & & & & & \\
\hline$\underline{11}$ & & & & & & & \\
\hline$\underline{12}$ & & & & & & & \\
\hline
\end{tabular}

\section{Copyrights}

Copyright for this article is retained by the author(s), with first publication rights granted to the journal.

This is an open-access article distributed under the terms and conditions of the Creative Commons Attribution license (http://creativecommons.org/licenses/by/4.0/). 